\section{Kidney \\ Blood Pressure Research}

Review

\title{
Early Predictors of Acute Kidney Injury: A Narrative Review
}

\author{
Xiaoqin Liu Yi Guan $^{\mathrm{b}}$ Sheng Xuc Qingzhao Lid ${ }^{\mathrm{c}}$ Yuanbo Sun ${ }^{\mathrm{a}}$ Ruijie Han \\ Chunyang Jiang
}

aDepartment of Nephrology, Hongqi Hospital, Mudanjiang Medical College, Aimin District,

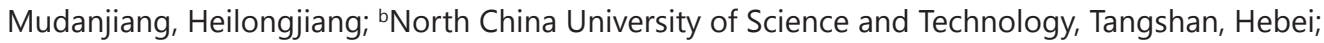
'Department of Neurosurgery, Tangshan People's Hospital, Tangshan, Hebei; dHebei Province Key Laboratory of Occupational Health and Safety for Coal Industry, North China University of Science and Technology, Tangshan, Hebei; 'Department of Thoracic Surgery, Tianjin Union Medical Center, Hongqiao District, Tianjin, People's Republic of China

\section{Key Words}

Acute kidney injury • Biological marker • Diagnosis • Treatment

\begin{abstract}
Accompanied with the broad application of interventional therapy, the incidence of acute kidney injury (AKI) has been recently increasing in clinical renal medicine. The pathogenesis of AKI is diverse and complex. In the context of the requirements for the diagnosis and treatment of a renal disorder, a large number of studies have explored biological markers and their usefulness to the early diagnosis and treatment of AKI, including glomerular injury, renal tubular injury, and others. These biomarkers provide an important basis for early monitoring of AKI, but are still not quite sufficient. More ideal biomarkers are needed to be identified. Therefore, future studies are necessary to explore more effective biomarkers for AKI clinical practice, which would play an important role in the early diagnosis and intervention treatment of AKI. This review summarizes the important biomarkers identified by previous studies and aims to highlight the advancements that might provide new methods for early clinical diagnosis and effective therapeutic options, along with prediction of response to treatment for AKI.
\end{abstract}

X. Liu, Y. Guan and S. Xu contributed equally to this work and therefore share first authorship.

Chunyang Jiang, and

Xiaoqin Liu

KARGER
C.J.: Department of Thoracic Surgery, Tianjin Union Medical Center, 190 Jieyuan Road, Hongqiao District, Tianjin 300121, Tianjin, (P. R. China), Tel. +86 22 27557493, E-Mail chunyangjiang@126.com. X.L.: Department of Nephrology, Hongqi Hospital, Mudanjiang Medical College, Aimin District, Mudanjiang, Heilongjiang (People's Republic of China), Tel. +86 453 6582800, E-Mail 413078159@163.com 


\section{Kidney Blood Pressure Research}

Kidney Blood Press Res 2016;41:680-700

DOI: 10.1159/000447937

\begin{tabular}{ll} 
Published online: September 28, 2016 www.karger.com/kb \\
\hline
\end{tabular}

Liu et al.: Early Predictors for AKI

This review summarizes the current clinical and research progress of some important biomarkers in the field of acute kidney injury (AKI). In recent years, the incidence of contrast medium-induced acute kidney injury (CI-AKI) has gradually increased along with the broad application of interventional therapy, which is gaining increasing attention. According to the Kidney Disease: Improving Global Outcomes (KDIGO) (2012) clinical practice guideline for AKI, it is a common clinical problem defined by an abrupt $(<48 \mathrm{~h})$ increase in serum creatinine (Scr) resulting from an injury or insult that induces an abnormal kidney structure and function, including blood, urine, and tissue tests or imaging markers of renal injury in terms of an exception, persists for more than $6 \mathrm{~h}$. Current diagnostic criteria include sharp decline in renal function manifested by increase in serum Scr levels within $48 \mathrm{~h}$ after injury $(\geq 0.3 \mathrm{mg} / \mathrm{dl}(\geq 26.5 \mu \mathrm{mol} / \mathrm{L})$ or increase in Scr to $\geq 1.5$ times baseline within the previous 7 days or urine output $<0.5 \mathrm{ml} / \mathrm{kg} / \mathrm{h}$ for $6 \mathrm{~h} \mathrm{[1]}$. These new criteria with a lower demand for baseline Scr values determine the diagnosis time window and meanwhile emphasize the importance of urine volume. How an earlier diagnosis of AKI can be achieved is a question that has received extensive attention in various related disciplines, such as cardiovascular medicine, nephrology, emergency medicine, and laboratory medicine.

AKI is a complex process resulting from multiple causes, including renal medullary ischemia caused by insufficient renal perfusion and renal vasoconstriction, decreased glomerular filtration rate (GFR), renal tubular obstruction, and remodeling and metabolic changes of renal tubular epithelial cells. Today, kidney ischemia/reperfusion (I/R) is regarded as an important process of AKI. There are two important factors to be considered here: 1) Vascular factors, including renal vasoconstriction; decreased renal blood flow; drop in glomerular blood pressure, which result in lateral medullary ischemia, leading to aggravation and activation of tubuloglomerular feedback; ischemic tissue damage; or cell necrosis. 2) Renal tubule factors, including obstruction of renal tubules, reabsorption dysfunction, and renal interstitial inflammation [2]. In addition, oxidative stress response activated by inflammatory mediators produced from damaged epithelial cells and the release of various vasoconstrictor substances can all aggravate ischemic damage [3], especially of proximal straight tubule (S3 segment) and medullary thick ascending limb. As a traditional biochemical marker for the diagnosis of AKI, Scr is not sensitive enough for early monitoring. Elevated Scr level is the consequence of loss of glomerular ultrafiltration capacity. On one hand, several AKI cases occur due to acute renal tubular necrosis caused by ischemia or toxic substances, but they do not directly correlate with glomerular damage. On the other hand, the glomerulus has powerful compensatory capacity, and Scr usually begins to rise days or even weeks after AKI onset when GFR decreases by one-third to half, but not obvious in the diagnosis time window ( $48 \mathrm{~h}$ ). In addition, Scr level can be influenced by several interference factors, such as age, sex, race, prerenal factors, muscle mass, metabolism, and nutrition status.

Further in-depth research on the pathogenesis of AKI has resulted in biological makers with a higher sensitivity and stronger specificity that have played an important role in the early diagnosis and early intervention treatment of AKI. This review summarizes a certain important biomarkers and the current progress of clinical and research issues in this field.

\section{Biomarkers of glomerular injury}

Matrix metalloproteinase 9 (MMP-9)

Matrix metalloproteinase family is named after their metal-ion cofactors (calcium, zinc, or other metal ions). Members of this protein family generally have a similar structure containing five domains with different functions, including the signal peptide region, propeptide region, and catalytic domain, which are highly conserved. MMP-9 (92-kDa type IV collagenase, gelatinase B) was recognized as a marker of glomerular injury that is primarily expressed in the glomerulus and plays an important role in tissue development and stability of internal environment. MMP-9 levels in patients with sepsis were significantly increased compared with the control group at $6 \mathrm{~h}$ and reached the peak value at $12 \mathrm{~h}$. A study has found that, in animal models, renal ischemia reperfusion injury was associated 


\section{Kidney Blood Pressure Research}

with increased MMP-9 levels, which can regulate the glomerular and renal tubular vascular changes and enhance the permeability of renal tubules [4]. Urinary MMP-9 concentration was significantly improved in patients suffering from AKI compared with patients with chronic kidney disease and healthy individuals, suggesting that MMP-9 may play a role in the early phase of nephropathy, but its application has been limited because of its high susceptibility to inflammatory factors such as urinary tract infections.

\section{Cysteine-rich 61 (Cyr61)}

Cyr61 is a heparin-binding, extracellular matrix-associated protein of the CYR61/ CTGF/NOV (CCN) family and is a ligand of integrin receptor, with a molecular weight of 42, 000 Da. Cyr61 has multiple functions: induction of angiogenesis in vivo, purified Cyr61 mediates cell adhesion and induces adhesive signaling, stimulates cell migration, enhances cell proliferation, accelerates tissue remodeling and wound healing, promotes cell survival in both fibroblasts and endothelial cells, participates in the composition of membrane and extracellular matrix, and it is also involved in membrane formation, cytophagy and pinocytosis, membrane transport, cytoskeleton stability, ion channel formation and opening, and ion flow regulation of glomerular ultrastructure. In the renal tissue of healthy adults, Cyr61 is secreted by podocytes and has a protective effect on mesangial cells, including promotion of mesangial cell migration, inhibition of mesangial cell adhesion, enhancement of glomerular cell repair, and prevention of glomerular capillary occlusion. Animal experiments and clinical studies have confirmed that the proximal straight tubule (S3 segment) can be induced to produce Cyr61 3-6 h after renal ischemic damage, and its level increased significantly, reached a peak at 6-9 h, and then gradually decreased [5]. Cyr61 was initially considered as a marker of renal tubular damage, whereas a recent study found that podocyte Cyr61 expression was significantly decreased in the renal biopsy tissues of patients with glomerular diseases, suggesting that Cyr61 is a sensitive marker of podocyte damage and can be used for diagnosis of AKI as marker of glomerular damage [6]. There are two factors limiting its clinical application: 1) Cyr61 disappears very quickly in urine. In an experimental model of ischemia reperfusion, urinary Cyr61 decreased rapidly, along with continuing kidney damage aggravation; 2) the sensitivity and efficiency of Cyr61 test methods, such as heparin magnetic agarose bead purification technology, are not significant.

Cystatin C (CysC)

CysC belongs to the cysteine proteins inhibitors family with a 122-amino acid structure of low molecular weight (13 kDa). It is synthesized and released into plasma by all nucleated cells at a constant rate, can be freely filtered by the glomerulus due to its small size and positive charge, and is completely reabsorbed and degraded but not secreted by renal tubules. Hence, serum CysC is an early biomarker of AKI that can reflect the early changes in renal function and the decline of GFR. Initially, it was believed to be less influenced by factors such as weight, age, and gender. However, subsequent studies revealed that CysC concentration was higher in patients with greater height, body weight, age, and muscle content [7]. The time period of CysC increase was slightly different due to the initial cause of AKI and patient's age. A prospective single-center study showed that compared with a non-AKI group, CysC levels in pediatric patients with AKI were significantly increased $2 \mathrm{~h}$ after cardiopulmonary bypass surgery, suggesting that it may be a good biological marker for early diagnosis of AKI [8]. Similarly, Krawceski et al [9] found that Cys $\mathrm{C}$ is a sensitive and specific marker for children who developed AKI $12 \mathrm{~h}$ after cardiac surgery. Haase Fielitz et al [10] found that blood CysC had $71 \%$ sensitivity and 53\% specificity for diagnosing AKI in adults within $6 \mathrm{~h}$ after cardiac surgery. Recent studies showed that within $12 \mathrm{~h}$ after pediatric cardiopulmonary bypass surgery, serum CysC level was significantly elevated in patients who developed AKI [11] and increased significantly $8 \mathrm{~h}$ after percutaneous coronary interventions in patients who developed CI-AKI [12].

Several studies have confirmed that serum CysC can diagnose AKI earlier than Scr [13, $14]$, but later than neutrophil gelatinase-associated lipocalin (NGAL) $[15,16]$. Serum CysC can detect AKI 1-2 days earlier than Scr, and its sensitivity was also significantly higher than that of Scr. Using 99 mTc-DTPA clearance as index of glomerular filtration function, Uzun et 


\section{Kidney Blood Pressure Research}

al [17] found that the sensitivity of CysC for diagnosing renal insufficiency was $82.8 \%$, while that of Scr was only $68.2 \%$, thus CysC is easier to detect. Therefore, as a marker of kidney function, CysC is more ideal than Scr [18]. The areas under the curve of CysC and Scr were 0.728 and 0.901 , respectively, in patients with traumatic hemorrhagic shock. Although CysC levels were significantly increased in the early stage and can serve as a predictor of AKI, its value in early diagnosis of traumatic hemorrhagic shock was still lower than Scr [19].

Till date, serum CysC has been recognized as an ideal index of GFR, with a high sensitivity and specificity. Some factors, including storage conditions, muscle mass, age, gender, diet, infections, inflammation, and tumor may not affect serum CysC levels, but CysC may be influenced by thyroid dysfunction, immunosuppressant use (e.g., glucocorticoids), smoking, systemic inflammatory response, and elevated C-reactive protein [20]. Its widespread application in clinical has been limited because of lack of a standardized test.

\section{Renal tubular injury biomarkers}

Tissue inhibitor of metalloproteinase-2 (TIMP-2)

Matrix metalloproteinase gene family member MMP-2 gene located on human chromosome 16q21 comprises 13 exons and 12 introns in its composition, with a total length of $27 \mathrm{~kb}$. Activated MMP-2 is located at the protruding points where cells, through matrix, may play a "Bit" role in enzymolysis of collagen type IV, the primary component of intercellular matrix and basement membrane. TIMP-2 is a natural inhibitor of MMP-2 and participates in the regulation of cell growth and apoptosis [21]. TIMP2 is one biomarker for cellular stress in the early phase of tubular cell injury caused by a wide variety of insults (oxidative stress, inflammation, ischemia, drugs, and toxins). When DNA damage occurs, the levle of protein TIMP-2 would increase in renal tubular cells. TIMP-2 is a G1 phase blocker that can induce a temporary G1 arrest, thus avoiding the possibility of cell damage. A study in an in vivo rat model of kidney ischemia-reperfusion showed that TIMP-2 expression was significantly increased after renal ischemia for $12 \mathrm{~min}$ [22]. In addition, Jiang et al [23] found that compared with healthy controls, TIMP-2 levels were significantly increased in patients with lupus nephritis. Furthermore, another multicenter study showed that urine TIMP-2 was more sensitive than other markers (such as NGAL and IL-18) in the prediction of moderate to severe AKI (grades 2-3, KDIGO) within $12 \mathrm{~h}$, suggesting that it can be used as a new selectable marker for AKI. TIMP-2 is involved with the phenomenon of G1 cell cycle arrest during the very early phases of cell injury [24].

Kidney injury molecule 1 (KIM-1)

KIM-1 is a $100 \mathrm{kDa}$, type I transmembrane glycoprotein member of the TIM family of immunoglobulin superfamily molecules, with an immunoglobulin and mucin domain and consisting of 359 amino acid residues. It was first isolated and characterized by Ichimura et al in 1998. As a biomarker of AKI, KIM-1 has been widely studied in recent years. It was found to be expressed at low to undetectable levels in normal kidney tissue but was markedly expressed in rodent kidneys with dedifferentiated proximal tubular epithelial cells after ischemic or toxic injury [25]. It was undetectable in completely atrophic renal tubular epithelial cells and, therefore, may play an important role in early tubular damage by modulation of damage or repair mechanisms. KIM-1 can exist stably at room temperature. The cell surface form (mature) of KIM-1 is a 104-kDa peptide, whereas the soluble form of KIM-1 that appears in urine of rodents and humans with renal injury is about $90 \mathrm{kDa}[26$, 27]. Urine KIM-1 levels are associated with KIM-1 protein expression in experimental and clinical renal disease [28]. KIM-1 can also serve as a blood biomarker of kidney injury [29]. As a new early biomarker for AKI, it was elevated at the early stage of AKI and also has predictive value for early diagnosis of chronic kidney disease [30].

KIM-1 is highly sensitive for the diagnosis of AKI. The expression of KIM-1 was markedly upregulated in the proximal tubule of renal biopsy tissues from patients with AKI. Several studies concluded that urinary KIM-1 levels were significantly elevated within few hours after kidney damage [31-33]. Plasma KIM-1 levels were higher in patients with AKI 


\section{Kidney \\ Blood Pressure Research}

Kidney Blood Press Res 2016;41:680-700

DOI: 10.1159/000447937

\begin{tabular}{ll} 
Published online: September 28, 2016 www.karger.com/kb \\
\hline
\end{tabular}

Liu et al.: Early Predictors for AKI

than in healthy controls or post-cardiac surgery patients without AKI. It shows a positive correlation with duration of hypertension or ischemia and thus may be a potential predictor of renal damage caused by hypertensive nephropathy or ischemia reperfusion $[29,30]$. A single-center, nested case-control study of thirty-two patients who underwent coronary angiography demonstrated that KIM-1 can be used for early diagnosis and early initiation of treatment for CIN and thus reduce the risk of mortality [34]. Similar results were obtained in a study of patients with diabetes mellitus undergoing PCI, in which of the 145 diabetic patients undergoing PCI, 19 (13.1\%) patients exhibited CI-AKI, and there was a significant difference between urinary KIM-1 levels measured 2, 6, 12, 24, and $48 \mathrm{~h}$ after the procedure and those prior to the procedure in the CI-AKI group. The Scr concentration was positively correlated with the urinary KIM-1 level during the time prior to the procedure and 24 and $48 \mathrm{~h}$ after the procedure. Urinary KIM-1 may be a potential indicator for the early diagnosis of CI-AKI [35].

KIM-1 was reported as an AKI biomarker for the first time in 2002. Original studies showed that compared with other novel markers, the increase of KIM-1 level has a certain hysteresis, although in renal biopsy tissue of patients with acute renal tubular injury. The positive rate of KIM-1 could reach $100 \%$, even when $28 \%$ of the patients did not exhibit morphological changes of kidney. The results indicate that KIM-1 can detect renal tubular damage earlier than histological examination [36]. KIM-1 level was significantly increased as early as $3 \mathrm{~h}$ of renal I/R injury. Based on a large-scale analysis of AKI patients from 2002 to 2009, Huang Y et al. confirmed that KIM-1 was an early biomarker of AKI within $24 \mathrm{~h}$ after kidney injury [37]. Regarding the diagnosis specificity, Han et al. [26] demonstrated that urinary KIM-1 can precisely differentiate ischemic AKI from prerenal axotemia and chronic kidney disease. Its level was not influenced by urinary tract infections and contrast mediainduced AKI (CI-AKI) [38].

In a recent experimental renal toxicity study using rat model, KIM-1 was considered to be a predictor of renal tubule pathological damage. Urinary KIM-1 was superior to Scr and blood urea nitrogen in a variety of kidney damage [39]. In CI-AKI rats, KIM-1 levels in urine and renal tissue were elevated rapidly prior to a significant rise in Scr. KIM-1 showed a high sensitivity of $100 \%$ for diagnosis of AKI, and its specificity was even higher in the late stage $[40,41]$. Urinary KIM-1 was stable even after the urine was frozen and thawed for 4 cycles. Due to its noninvasive, conveniently good compliance and being not affected by the physicochemical properties of urine, the specificity was greater than NGAL in early AKI and the sensitivity was higher than N-acetyl-beta-D-amino glucoside enzyme (NAG) but lower than NGAL. Furthermore, KIM-1 level was consistent with the degree of pathological damage [42-45]. In an experimental study of rat renal toxicity [46] using degree of pathological changes as a parameter for judging the severity of proximal renal tubular damage, the researchers found that KIM- 1 has the highest sensitivity and specificity in 21 types of urine detection indexes. KIM-1 has obvious advantages in AKI prediction, but the increased degree is varied according to the etiology of AKI. For example, a study involving 62 patients undergoing renal transplant has shown that KIM-1 levels in kidney tissues were significantly elevated in all patients who developed AKI. For patients with acute rejection, the rate reached even 92\% [47].However, there was no significant change in AKI patients with complicated nephrotic syndrome [44, 48].

KIM-1 can also serve as a repair indicator of kidney injury. It can induce apoptotic body phagocytosis by renal tubular epithelial cells, slough off necrotic renal tubular epithelial cells, and contribute to the recovery of renal tubular function. Overall, KIM-1 is an ideal indicator of renal function recovery after proximal tubular injury $[49,50]$. In the late stage of AKI, high KIM-1 expression is associated with renal fibrosis and chronic inflammation and may be an important predictor of progression of chronic kidney disease [51, 52].

Urinary KIM-1 expression was also associated with adverse clinical outcomes in AKI patients, including death and dialysis, [44] but it has no advantage in predicting the rate of progression to renal replacement therapy and mortality compared to Scr and urea nitrogen [26].

In conclusion, KIM-1 may be a good biomarker for kidney injury because of the following three reasons: First, it cannot be detected in normal renal tissue; second, it is 


\section{Kidney Blood Pressure Research}

expressed only in damaged proximal tubular epithelial cells, regardless of nephrotoxicity or the initial stage of ischemic injury; third, the ectodomain of KIM-1 is shed from cells, secreted into urine within $12 \mathrm{~h}$, and continue to exist until epithelial regeneration [53]. Urinary KIM-1 concentration is closely related to the severity of renal damage; thus, it can be used as a sensitive, noninvasive, and quantitative biomarker for diagnosis and monitoring of kidney injury [54]. KIM-1 is stable in urine and is not influenced by physical and chemical characteristics of urine, and hence has the potential to become an important marker for classifying renal injury. Currently, enzyme-linked immunosorbent assay (ELISA) is widely used in clinical tests, which is helpful to confirm the effectiveness of KIM-1[55]. KIM-1 was confirmed as a highly sensitive and specific biomarker for drug-induced kidney injury by the Food and Drug Administration (FDA) and the European Medicines Agency (EMEA) [56]. Nevertheless, KIM-1 levels increase slowly, usually lagging behind renal injury, and can be influenced by nephrotoxic drugs (such as cisplatin, ring spore element, gentamicin, and cadmium), inflammation, fiber lesions, and persistent proteinuria [57]. Therefore, combining with other sensitive markers such as NGAL/IL-18 can improve its diagnostic specificity.

NGAL

NGAL is the most extensively studied biomarker of AKI. It was originally identified in human neutrophils and later found to be distributed widely in immune cells and various tissues and organs, including trachea, lung, stomach, liver, colon, and kidney [58, 59]. NGAL is a member of the lipocalin superfamily of carrier proteins, which are approximately 25 $\mathrm{kDa}$ in size. A typical lipocalin fold of NGAL with an eight-stranded beta-barrel, but with an unusually large cavity lined with more polar and positively charged amino acid residues than normally seen in lipocalins. It is produced by activated neutrophils of proximal tubule, covalently bound to neutrophil gelatinase [60]. The expression level of NGAL is usually in low state, but can be secreted by epithelial cells, and is markedly elevated in pathological conditions [61]. It was shown to be involved in various physiological and pathological events such as inflammatory immune response, lipid metabolism, intracellular iron transport, renal tubular repair, and differentiation of kidney progenitor cells into tubular epithelial cells. NGAL is often expressed in tissues that frequently contact with microorganisms and thus plays a role in host defense.

In renal ischemia or toxic damage, NGAL was significantly increased in injured tubular (especially proximal renal tubular) epithelial cells. Meanwhile, besides inducing neutrophil apoptosis in renal tubular interstitial cells, NGAL protects from the invasion of inflammatory cells, by inducing renal interstitial cell conversion to tubular epithelial cells and promoting the repair and regeneration of renal tubular epithelial cells. This small molecular peptide can resist the effects of proteolytic enzymes and can thus be easily detected in urine samples. Therefore, it is an early, sensitive, and specific biological marker of ischemic or nephrotoxic injury. In various available biomarkers of AKI, only NGAL and cystine protease inhibitor C can be reliably detected by the automatic biochemical analyzer. NGAL appears to be a promising marker for early detection of AKI and is likely to be adapted for wide-scale clinical use in patient management as a point-of-care test; use of NGAL along with a panel of other renal biomarkers can improve the rate of early detection of AKI [62].

NGAL is a predictor of AKI caused by various reasons. A meta-analysis of data from 19 studies including 487 patients with AKI revealed that the NGAL levels in urine and blood have guiding significance for predicting early AKI [63]. NGAL demonstrated a sensitivity of $85 \%$ and specificity of $83 \%$ for predicting AKI after hematopoietic stem cell transplantation (HSCT). The changes of day +9 uNGAL concentrations from baseline could be of value for predicting AKI in HSCT patients [64]. NGAL levels can be used as an AKI biomarker after extracorporeal circulation cardiac surgery and aortic valve replacement; after aortic valve replacement, NGAL levels more than $136 \mathrm{ng} / \mathrm{ml}$ show an obvious correlation with early treatment intervention. In the prediction of the occurrence of AKI and early medical intervention, NGAL is superior to the traditional warning factor such as creatinine and hence can be used as a predictor of AKI occurring postoperatively after heart surgery $[65,66,67]$. In addition, the ability of NGAL to predict AKI primarily caused by body fluid loss and unbalanced perfusion has also been confirmed. Urinary NGAL can be detected within $3 \mathrm{~h}$ after acute 


\section{Kidney Blood Pressure Research}

Kidney Blood Press Res 2016;41:680-700

DOI: 10.1159/000447937

Published online: September 28, 2016 www.karger.com/kb

Liu et al.: Early Predictors for AKI

renal ischemia-reperfusion injury [68]. Whole blood NGAL significantly increased in burn patients who developed AKI during the first week after burn. NGAL is an early independent predictor of AKI during acute resuscitation for severe burn injury [69]. Elevated NGAL levels were observed in neonates with hypoplastic left-heart syndrome (HLHS) and diagnosed AKI stage 1 compared to those newborns without AKI. Umbilical blood NGAL could predict AKI in neonates with high sensitivity and specificity and its concentration may be an early marker to predict AKI in neonates with HLHS [70].

Several other studies also confirmed that NGAL has high sensitivity and specificity for the diagnosis of AKI. Makris et al [71] found that NGAL had a sensitivity of $91 \%$ and a specificity of $95 \%$ for ICU patients who developed AKI. However, some researchers also have reservations about the conclusions. A prospective study of organ transplant ICU patients showed that P-NGAL, U-NGAL/Cr, and L-FABP/Cr before ICU admission have no correlation with AKI, and there were no differences in P-NGAL, U-NGAL/Cr, and L-FABP/Cr levels from day 1 to day 6 between patients who did not recover from AKI and patients who recovered from AKI. NGAL and L-FABP upon ICU admission are not predictive of AKI, and serial NGAL and L-FABP measurements may be ineffective for monitoring the status and treatment of posttransplantation AKI [72].

Several studies have shown that NGAL has obvious advantages in the prediction of AKI (especially drug-induced AKI). Chemotherapy agents, such as cisplatin and carboplatin, have the primary side effect of renal toxicity. Urine NGAL/creatinine ratio was significantly increased in patients with cisplatin-associated AKI, urinary NGAL can be detected at $2 \mathrm{~h}$ after cisplatin infusion, and urinary NGAL-creatinine ratio within the first 24 hours after cisplatin infusion may be better than Scr to predict cisplatin-associated nephrotoxicity $[68,73]$. In another study, a total of 42 patients received platin compounds (cisplatin, carboplatin, or oxaliplatin), and the results also indicated that urinary NGAL seems to be promising in detecting AKI earlier than with creatinine [74]. Tacrolimus is a primary immunosuppressant after liver transplantation. In a study of 31 patients who underwent living donor liver transplantation (LDLT), 20 recipients developed tacrolimus-induced AKI, and urinary levels of NGAL, monocyte chemoattractant protein-1 (MCP-1), and liver-type fatty acid-binding protein were significantly higher in patients with AKI than in those without AKI. The predictive effect of urinary NGAL was stronger than other six biomarkers (MCP-1, liver-type fatty acid-binding protein, interleukin-18, osteopontin, cystatin C, and clusterin.) [75].

Additionally, NGAL may also be used to exclude drug-induced AKI. A recent study showed that after $6 \mathrm{~h}$ of contrast media exposure, urinary NGAL $<20 \mathrm{ng} / \mathrm{ml}$ and sNGAL $<179 \mathrm{ng} / \mathrm{ml}$ is a reliable sign that ruled out contrast agent-induced AKI [76]. NGAL can be used as an early biomarker for the evaluation of degree and prognosis of AKI. A study found that NGAL could independently predict 28-day mortality of AKI patients who require renal replacement therapy (RRT). Plasma and urine NGAL levels are important predictors for the occurrence and prognosis of AKI in critically ill patients, or AKI following heart surgery, and contrast administration and NGAL level were gradually increased with increasing severity of AKI [63].

It should be noted that both urinary and plasma NGAL levels have their own advantages and disadvantages. Plasma sample is easy to obtain, but it needs to have blood drawn. Therefore, it is an invasive procedure. Moreover, plasma NGAL may be influenced by bacterial infections, systemic inflammation, and malignancy [72]. The interference factors of urinary NGAL are relatively few, but they cannot be determined in patients with anuria [77]. Martensson et al [77] found that urine NGAL level was not increased in sepsis patients without AKI. Therefore, it may be an index to evaluate whether sepsis patients developed AKI. However, another study found that in patients without AKI, kidney tissue can also produce NGAL to increase its urinary excretion rate. The increased levels of UNGAL can also be due to overspill from the systemic circulation, which render the discriminative value of NGAL as a biomarker for AKI in patients with sepsis to become blurred $[63,78]$. Hence, the choice of the sample type should be according to the specific clinical situation [79].

In short, NGAL is one of the most valuable biomarkers for monitoring AKI, with high sensitivity and specificity [80], but it is easily affected by various interference factors, which seems to be more applicable for AKI patients with relatively fewer complications. 


\section{Kidney Blood Pressure Research}

\section{Interleukin-18 (IL-18) and IL-6}

IL-18 belongs to interleukin 1 family, with a molecular weight of $18 \mathrm{kDa}$, and is a novel cytokine that plays an important role in the T-cell-helper type 1 (Th1) response. It is produced by macrophages and renal tubular cells, playing active roles in several renal pathological processes, including ischemia or reperfusion, infection, autoimmune conditions, and malignant tumor. It also induces ischemic injury of the brain, heart, and kidney. Renal tubular epithelial cells are important sources of caspase-1 and IL-18. Pro-IL-18 can be quickly expressed after ischemic stimulation and activated by caspase- 1 and then involve in the process of kidney injury and recovery. The important role of IL-18 in ischemic AKI was originally confirmed in animal experiments, and then later, it was found that IL-18 may also be an important biological marker for human AKI. In 2004, it was first found that compared to prerenal axotemia, urinary tract infections, chronic renal failure, and nephrotic syndrome, the concentration of urinary IL-18 was significantly increased in AKI patients. IL-18 has been reported to increase about 2 days earlier than Scr. It is an early sensitive predictor of AKI, which is closely related to the severity of AKI and mortality rates [81]. In AKI patients, urinary IL-18 can be increased within 4-6 h, reaching the peak at $12 \mathrm{~h}$ and remaining significantly higher after $48 \mathrm{~h}$, which reveals a temporal relationship with urinary NGAL. The specificity and sensitivity of urinary IL-18 are both greater than $90 \%$ for the early diagnosis of AKI [81]. In pediatric patients who developed AKI 1-2 days after cardiac surgery, urinary IL-18 increased at $6 \mathrm{~h}$ after the surgery and peaked at over 25 -fold at $12 \mathrm{~h}$. Urinary IL-18 was highly correlated to the risk of AKI, and its level was closely related to the duration of AKI, indicating that it can be used to monitor the progression of AKI $[82,83]$.

Urinary IL-18 level was also associated with the severity and prognosis of AKI, which was significantly increased with the severity of AKI, using $100 \mu \mathrm{g} / \mathrm{L}$ as the critical value of diagnosis. IL-18 had a specificity of $93 \%$ to predict AKI duration $\geq 48 \mathrm{~h}$ [84]. Urinary IL18 is an independent risk factor for mortality and is associated with poor outcomes in AKI patients [85]. In a prospective study of critically ill ICU children with mechanical ventilation, Washburn et al [86] found that in urine of children with AKI, the change in IL-18 levels was at least 2 days earlier than Scr. Urinary IL-18 level was proportional to the severity of AKI. It not only was a sensitive indicator for critically ill patients developing AKI, but it can also effectively predict mortality. In addition, according to a study on AKI patients complicated with acute respiratory distress syndrome (ARDS), urinary IL-18 could predict mortality after mechanical ventilation [81]. Hall et al [87] found that IL-18 could accurately predict the need for dialysis within the first week of kidney transplantation.

IL-18 is the only predictive indicator for severe AKI. Studies involving 258 patients who underwent coronary artery bypass surgery confirmed that IL-18 could predict AKI after coronary artery bypass surgery $[81,88,89]$. However, some researchers have also indicated that IL-18 appears not to be valuable in identifying patients who develop AKI after cardiac surgery $[90,91]$.

The detection of IL-18 is fast, reliable, and inexpensive, with good a prospect. IL-18 can be tested by ELISA method, and it has a great advantage compared with other biological markers [92]. While as a proinflammatory cytokine, IL-18 plays an important role in sepsis [93]. However, its levels may be affected by several factors, including endotoxin, inflammation, and immune factors. Serum IL-18 increased in some pathophysiological conditions, such as arthritis, systemic lupus erythematosus (SLE), inflammatory bowel disease, psoriasis, hepatitis, and multiple sclerosis [94]. Thus, this cytokine only can be a potential indicator for AKI, and the proinflammatory effects and increment adjustment role in inflammatory diseases may affect its sensitivity and specificity.

The proinflammatory cytokine IL-6 has been widely expressed during tissue injury (e.g., sepsis), which is filtered through the glomerulus, reabsorbed, and metabolized in proximal tubules. It was significantly increased in animal models of ischemic and toxic AKI. In the study of AKI following cardiac surgery, IL-6 was increased in AKI group within $6 \mathrm{~h}$ postoperatively, with the sensitivity in diagnosing AKI reaching 88\% [95]. For kidney allograft, compared to clinical acute inflammation, subclinical acute kidney inflammation has lower extend of transcriptional profile of immune injury and inflammatory mediator 


\section{Kidney Blood Pressure Research}

Kidney Blood Press Res 2016;41:680-700

\begin{tabular}{l|l}
\hline DOI: 10.1159/000447937 & (C) 2016 The Author(s). Published by S. Karger AG, Basel
\end{tabular}

Published online: September 28, 2016 www.karger.com/kbr

Liu et al.: Early Predictors for AKI

such as cytokine receptors (CCRL2, CCR1, CXCR5, IL1RAPL2), proinflammatory cytokines (LTA, IL12A), complement protein C3 and inflammatory mediator (PTAFR) [96].

Liver-type fatty acid-binding protein ( $L-F A B P$ )

FABP belongs to the fatty acid-binding protein superfamily; it is a small, highly conserved cytoplasmic protein that binds long-chain fatty acids, with a molecular mass of about $14 \mathrm{KD}$, and widely exists in metabolically active adipose tissue, expressed at high abundance in the mammalian liver, but with low expression in the pancreas, kidney, and intestine. So, far, two different FABPs have been identified in human kidney, L (liver-type)FABP is located predominantly in the proximal tubular system, while $\mathrm{H}$ (heart-type)-FABP is primarily found in the distal tubular system. Under normal physiological conditions, L-FABP is released into the blood circulation, glomerular filtration, and in renal tubular reabsorption [97]. Hence, L-FABP is primarily expressed in proximal tubules, associated with the severity of renal tubular injury. L-FABP level is correlated with the peritubular capillary blood flow and ischemic time in kidney transplantation and can be used for monitoring the process of acute ischemic renal injury, chronic kidney disease, diabetes, and IgA nephropathy [98].

Elevated FABP serum concentrations are related to a number of common comorbidities, such as heart failure, chronic kidney disease, diabetes, and metabolic syndrome, which represent important risk factors for postoperative AKI. Urinary L-FABP seems to have a similar effect. Several studies have demonstrated that urinary L-FABP was significantly increased in a short time in AKI patients caused by various reasons (such as heart surgery, sepsis and renal tubular necrosis, and contrast nephropathy) [99-101]. Portila et al found that the sensitivity and specificity of urinary L-FABP to predict AKI after cardiac surgery were $71 \%$ and $81 \%$, respectively [102]. A study of 84 patients undergoing allogeneic stem cell transplantation found that high urinary L-FABP was an independent risk for the emergence of AKI. Increased baseline urinary L-FABP may indicate previous incipient kidney injury and was linked with a high risk of AKI after allogeneic stem cell transplantation [103]. Urinary L-FABP was significantly increased prior to the impairment of renal tubular function, and hence urinary L-FABP may be a sensitive indicator for early diagnosis of kidney disease [104]. Noiri et al [105] found that in a rat model of AKI and chronic kidney disease, urinary L-FABP may serve as a new marker of renal function superior to Scr. Urinary L-FABP can be detected at $24 \mathrm{~h}$ in cisplatin-induced and ischemia-reperfusion AKI animal model, while elevated Scr cannot be detected until $72 \mathrm{~h}$ later, suggesting that urinary L-FABP was more sensitive than Scr concentration as a marker of renal function. The range of dynamic monitoring of L-FABP was broader than Scr and can indirectly reflect the decline in GFR [106].

In addition, mortality in AKI patients diagnosed by Scr was increased remarkably when urinary L-FABP and NAG were positive. Both these biomarkers can specifically detect highrisk patients among creatinine-based diagnosed AKI [107]. Recent studies have further confirmed its efficiency in clinical diagnosis of AKI. Furthermore, L-FABP levels showed a significant positive correlation with days of hospitalization and mortality. These findings indicate that L-FABP was more sensitive to predict early AKI and it may be a good biomarker for AKI diagnosis and prognosis [100, 101, 108].

\section{$\mathrm{Na}^{+} / \mathrm{H}^{+}$exchanger isoform 3 protein (NHE3)}

NHE3 was mostly present on the apical membrane of cells in the proximal tubule and the loop of Henle, as the major transporter responsible for reabsorption of filtered $\mathrm{Na}+$ and HCO3 in the proximal tubule. At early stage of renal damage, followed by brush border damage and tubular necrosis, the intracellular fluid and apical membrane are released into the tubular fluid, resulting in increased urinary NHE3. Urinary NHE3 can be detected in ICU patients with AKI, which can discern AKI subtypes (prerenal, intrinsic renal, or post renal), and distinguish between the underlying causes, including prerenal axotemia, obstructive nephropathy or urinary tractinfections, and thus can be used as a specific, noninvasive marker for tubular damage [109]. However, the complexity of specimen processing limits its clinical application; urinary NHE3 threshold for AKI of unknown etiology is yet undetermined. For this reason, further research is needed to verify the effectiveness of NHE3. 


\section{Kidney Blood Pressure Research}

\section{$\beta 2$-Microglobulin $(\beta 2-M G)$}

$\beta 2-\mathrm{MG}$ is a protein widely distributed on the cell surface in a form noncovalently associated with the $\alpha$ chain of the class I major histocompatibility complex (MHC) molecules. Because of its small molecular weight, $\beta 2-\mathrm{MG}$ has the ability to be freely filtered through the glomerular wall into the tubule, about $99.9 \%$ of $\beta 2-\mathrm{MG}$ is reabsorbed by lysosomal degradation of amino acids rather than back into the blood; therefore, the normal urinary $\beta 2-M G$ content is small, and only the renal tubular damage and urinary $\beta 2-M G$ will increase. Therefore, it may be one of the sensitive markers of proximal tubule injury [110] and is now being implemented in clinical uses.

\section{Retinol-binding protein (RBP)}

$\mathrm{RBP}$ is a $21-\mathrm{kDa}$ plasma protein and a specific transport protein for vitamin $\mathrm{A}$, which is known as one of the liver synthetic vitamin A transporters. Through all-trans-retinol to stimulate and with the specific binding, the formation of retinol-RBP complex (HoloRBP), RBP is then secreted into the circulation in a 1:1:1 complex with ROH (holo-RBP4) and transthyretin (TTR), which can be taken up by target tissues until being filtered in the glomerulus, reabsorbed, and degraded in proximal tubular epithelial cells. Urinary RBP was highly sensitive to renal tubular dysfunction caused by various types of AKI and elevated prior to urinary NAG, more stable than $\beta 2-\mathrm{MG}$ in acidic urine. Roberts et al reported that [111] neonatal Scr level was largely dependent on maternal Scr level. It is difficult to determine renal damage by Scr; however, the increased RBP level during the first 2 days of life was predictive of clinically significant AKI in infants following birth asphyxia. However, as a vitamin A transporter, its detective value was depressed in patients with vitamin A deficiency. Almost all of RBP through glomerular filtration is reabsorbed and degraded in the proximal renal tubule. As an AKI biological marker, its specificity is not ideal enough in patients with heavy glomerular proteinuria or high filtration state. Its detection has been often limited by the occurrence of saturation of tubular reabsorption.

\section{Clusterin}

Clusterin is a heterodimeric glycoprotein of approximately $80 \mathrm{kDa}$, with high modification efficiency such as glycosylation, division, and forming dimmers, playing roles in lipid transport, cell-cell interaction, regulation of the complement cascade, and apoptosis initiation during renal injury. In AKI caused by nephrectomy, polycystic kidney, and renal cell carcinoma, the expression of clusterin on dedifferentiated tubular cells was significantly increased as KIM-1 [112]. One study found that in a rat model of unilateral ureteral obstruction, the clusterin mRNA expression was significantly increased in injured renal tubular epithelial cells, and its content in urine elevated at the same time, suggesting that clusterin can serve as an early biomarker of AKI [113]. The renal tissue still maintains the normal morphology when clusterin emerges in tubular injury location, and thus it can be used as an early marker of renal damage.

\section{Osteoactivin}

Osteoactivin is a glycoprotein containing 572 amino acids, with a molecular weight of $65,000-115,000$ daltons, and plays an important role in the regulation of myofibroblast differentiation, osteoblast growth, and osteoclast differentiation. Animal experiments have shown that osteoactivin expression can be observed even in the early stage of acute cyclosporine A-induced nephrotoxicity, which was more sensitive than Scr. It is primarily expressed in renal tubular epithelial cells and interstitial cells. The early-phase upregulation of osteoactivin expression in the tubular epithelium in response to renal injury caused by acute CsA toxicity might play a key role in triggering renal interstitial fibrosis via activating the expression of MMPs and collagen remodeling in SD rats, suggesting that it can serve as an early indicator of renal tubular damage and predict the effect of targeted therapy. Further studies are needed to determine the specific biological effects and its mechanism in renal fibrosis [114]. 


\section{Kidney Blood Pressure Research}

Kidney Blood Press Res 2016;41:680-700

DOI: 10.1159/000447937

\begin{tabular}{ll} 
Published online: September 28, 2016 www.karger.com/kb \\
\hline
\end{tabular}

Liu et al.: Early Predictors for AKI

Tubular marker enzymes

In recent years, several studies have shown that some proteins, especially enzymes released from the damaged proximal or distal renal tubular cells, can predict early tubular damage, and enzyme activities were positively correlated with the degree of damage [115]. Currently, diagnostic tubular marker enzymes are primarily derived from two parts of renal tubular epithelial cells: brush border membrane and cytolysosome. Therefore, these urinary enzymes can indicate the damage position as well as severity; glutathione S-transferase (GST), $\gamma$-pancreatic acyltransferase $(\gamma$-GT), alkaline phosphatase (AP), $n$-acetyl- $\beta$-d-amino glycosidase (NAG), and $\beta$-galactose glucoside( $\beta$-GAL) are mostly studied at present.

GST is a soluble cytosolic enzyme with two subtypes: $\alpha \& \pi$ respectively expressed in the proximal convoluted tubule and distal convoluted tubule. It can be detected in urine before Scr increased in patients with various kidney damages. $\gamma$-GT and AP are brush border enzymes, and their increased secretion indicates the damage of brush border. NAG is a lysosomal enzyme that primarily exists in the proximal convoluted tubule. Increased urinary NAG level indicates renal tubular epithelial cell injury and is one of the sensitive and long-lasting indexes of renal tubular damage. Urine NAG still has several advantages besides being sensitive and "quantitative" and positively correlated with proximal renal tubular damage degree. However, some damage factors outside of renal tubular damage, such as industrial solvents, heavy metals, and certain disease states (including rheumatoid arthritis, abnormal glucose tolerance, and hyperthyroidism patients), and lysosome activity elevation (such as protein increase from glomerular filtration and renal tubular reabsorption) can lead to elevated urinary NAG. All of these produced certain influences on its sensitivity and specificity $[116,117]$.

$\beta$-GAL is a lysosomal enzyme derived from renal tubular epithelial cells, exists in newborn lysosomes with more vigorous metabolism, and was found to be moderately increased in active pyelonephritis and active glomerulonephritis. Significantly increased $\beta$-GAL level in acute tubular necrosis and acute kidney transplantation rejection can be an index for repair effectiveness after lysosomal damage. The change curve of the GAL has certain differences in different types and period of renal parenchyma damage, combined with urine NAG enzyme spectrum analysis, and can be used for the diagnosis and prognosis observation of various renal injuries. Renal tubular marker enzyme testing is simple and convenient, but there is a problem of threshold setting. If the threshold is set too low, the sensitivity will be too high, leading to renal tubular lesion being misdiagnosed as AKI. There is still a need for considerable research work for setting an appropriate forecast threshold, closely combined with clinical requirements, meanwhile, and joint detection with other markers.

In addition, there are also plenty of tubular marker enzymes such as keratinization cell-derived chemokine (KC) and its human isomorphic Gro- $\alpha$, urinary transferrin (TRF), urine cluster, galactose lectin 3 , perforin protein and enzyme B particles, bone protection and variety of urinary enzymes, including urinary n-acetyl- $\beta$ glucose glycosidase, GSH-Stransferase, $\gamma$-pancreatic acyltransferase, alkaline phosphatase, and $\alpha-2$ microglobulin. All of them can reflect the renal tubular reabsorption function and degree of damage. Their sensitivity and specificity degree were relatively higher than those of Scr. However, they also have several shortcomings for defining AKI primarily because of several factors influenced by clinical application, lack of threshold standards, unstable detection level, and complicated detection method.

\section{Noncoding RNA}

Using circulating DNA and other genetic materials as biomarkers of various tissue injuries, cancer and fetal situations have achieved more and more attention. TrAnscript Predicting Survival in AKI (TapSAKI) was enriched in tubular epithelial cells subjected to ATP depletion. The expression of plasma long noncoding RNA (lncRNAs) was upregulated in patients with AKI. The alteration of circulating concentrations of IncRNAs in patients with AKI supports TapSAKI as a predictor of mortality. TapSAKI can be used as an independent predictor of 28-day survival [118]. 


\section{Kidney Blood Pressure Research}

Gutierrez-Escolano et al used an miRNA microarray assay to detect CIN miRNAs in kidney tissues in a rat model and found that a total of 51 species of miRNAs showed abnormal expression in the renal tissue of CIN rats. Among them, 17 kinds of miRNAs in CIN rat kidney tissues increased more than two times than in control group rats, and only 6 of the 17 also showed abnormal expression in CIN rat plasma. Compared with CIN group rats, the expression of miR-320 and miR-30 family (miR-30a, miR-30c, and miR-30e) was significantly increased in CIN rat plasma, but the miRNAs let-7a and miR-200a were significantly reduced. In validation studies using human plasma samples, only miR30a, miR-30c, and miR-30e increased in CIN patients more than two times compared to non-CIN patients, confirming that plasma miRNAs, especially three members of the miR-30 family (miR-30a, miR-30c, miR-30e), may be the early markers and/or candidate targets for CIN [119].

\section{Others}

\section{Netrin-1}

Netrin-1 is a small, secreted protein associated with laminin, ranging in molecular weight from 50, 000 to 75, 000, and plays an important role in the formation of new blood vessels, cell adhesion, and tumorigenesis. It was initially found to be widely expressed in the nervous system and was later found in a variety of tissues and organs (lung, pancreas, breast, kidney, and blood vessels), regulating their growth, differentiation, and migration [120]. In healthy renal tubular epithelial cells, Netrin-1 has no or low expression, but it is significantly expressed during the recovery phase of ischemic AKI caused by toxins, fatty acids, and ischemic renal tubule cells $[58,121]$. There were reports that the expression of Netrin-1 was significantly increased in AKI caused by various etiologies, including ischemic injury [122], and thus plays a protective role through promoting kidney epithelial cell proliferation and inhibiting apoptosis [123]. Ramesh et al [124] found that urinary Netrin-1 level began to increase at $2 \mathrm{~h}$ after cardiopulmonary bypass, reached the peak at $6 \mathrm{~h}$, and maintained a high level at $48 \mathrm{~h}$. In addition, the increased degree was related to the severity and duration of AKI; therefore, Netrin-1 can be used as an early predictor marker of AKI after cardiopulmonary bypass. Four mice models of renal injury have shown that Netrin-1 could be secreted into urine within $1 \mathrm{~h}$ of renal injury, and increased to 30-40 times $3 \mathrm{~h}$ later, which was earlier than the elevated Scr and urea nitrogen. In a renal ischemia animal model, urinary Netrin-1 increased quickly within $3 \mathrm{~h}$ and $6 \mathrm{~h}$, reaching the peak, and then began to decline close to baseline values within $72 \mathrm{~h}$. However, Scr elevated until $24 \mathrm{~h}$ after reperfusion. These results demonstrated that urinary Netrin-1 is a predictor biomarker of early renal damage [125]. Compared with NGAL, NAG, KIM-1, and Cyr61, Netrin-1 is secreted into the urine rapidly when kidney damage occurs and is returned to the normal level after perfusion; thus, Netrin- 1 can also be used to evaluate the prognosis of renal function recovery [126]. For renal transplantation patients with delayed function recovery, Netrin-1 may play a role as a survival factor in the recovery process after ischemia-reperfusion. Low Netrin-1 gene expression was closely related to delayed graft function after kidney transplantation. Recently, a study showed that Netrin 1 may play an important role in the protection of diabetic nephropathy [127]. Above all, Netrin-1 can be used as an early diagnostic marker of AKI, but urinary Netrin-1 was significantly higher in AKI patients caused by ischemia, contrast agents, drugs, and sepsis than that in normal healthy people [128]. Further studies are still needed to clarify the underlying mechanism of this protective function.

\section{Fetuin- $A$}

Fetuin-A is a negative acute phase protein synthesized by the liver and released into the circulation. The pathological significance of Fetuin-A in AKI is still not clear, but it may related to apoptosis of renal tubular cells. Recent experimental evidence shows that in cisplatin-induced renal damage, Fetuin-A was significantly increased at day 2 (1 day before Scr increase and tubule damage) and remained elevated at day 5 after cisplatin injection. Elevated urinary Fetuin-A levels were also observed in kidney ischemia-reperfusion injury, but not in prerenal azotemia [129]. The disadvantage of Fetuin-A is that a defect in the 


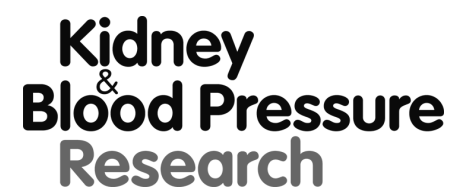

Kidney Blood Press Res 2016;41:680-700

\begin{tabular}{l|l}
\hline DOI: 10.1159/000447937 & ( 2016 The Author(s). Published by S. Karger AG, Basel
\end{tabular}

Published online: September 28, 2016 www.karger.com/kbr

Liu et al.: Early Predictors for AKI

method of separation and its detection and the sensitivity, efficiency, and quantification limits its clinical application [130]. The low separation and detection sensitivity and the shortcomings in the current methods of efficiency, identification, and quantification may all limit its clinical application [131].

Insulin-Like Growth Factor-Binding Protein 7 (IGFBP7)

IGFBP7 is a new member of IGFBPs. It is a kind of glycoprotein with a molecular weight of $30 \mathrm{KD}$, which can be secreted by epithelial cells, endothelial cells, and smooth muscle cells $[131,132]$. It can be detected in plasma, urine, bowel, bladder, and kidney [133, 134]. In kidney damage caused by sepsis or ischemia, renal tubular epithelial cells involved in cell cycle G1 block, IGFBP7 precisely is an inducer of G1 phase block [135-137]. IGFBP7 can prevent cell division in the case of DNA damage and block the division process until DNA damage has been fixed in order to avoid apoptosis, which may be a response mechanism of early AKI [138]. Aregger et al [139] indicated that compared with NGAL, IGFBP7 was likely to be a more accurate predictor for prognosis of AKI. A large sample study combined urine IGFBP7 and TIMP-2 to predict the occurrence of AKI, and the results showed that to predict the prognosis of AKI, urinary TIMP-2 and IGFBP7 were more sensitive than using only one or other markers (NGAL, KIM-1, IL-18, etc.)[140, 141].

\section{Trefoil factor 3 (TFF3)}

TFF3 family is a group of small molecule polypeptides, also known as Intestinal Trefoil Factor (ITF). The relative molecular weight of a single polymer is 6,692,000 and for dimers, it is $13,146,146$. It has important implications in mucosal repair, cell protection, and apoptosis. Among the biological markers, TFF3 is a research hot spot of kidney injury. TFF3 is small molecular peptide hormone secreted by human mucous cells and epithelial cells of various tissues. Each TFF3 molecule is composed of 59 amino acids and contains $1 \mathrm{P}$ domain structure. The primary function of TFF3 is to maintain and repair the surface of the mucous membrane. Urine TFF3 was significantly reduced following renal tubular damage, and prior to tissue toxicity, it changes and reaches the level of Scr. A study showed that decreased urinary TFF3 levels were significantly associated with aging of rats. TFF3 level has no obvious change when no kidney injury occurs, and urinary TFF3 level significantly decreases before Scr is elevated in outer medullary renal tubular damage, suggesting that TFF3 can be used as a sensitive marker of AKI [142].

Monocyte chemotactic protein 1 (MCP-1)

MCP-1 mRNA expression was increased in kidney ischemia-reperfusioninjury; therefore, after the local ischemic renal injury, MCP-1 can be used as a biomarker of mononuclear cells participating in the inflammatory process. Long-term studies have found that MCP-1 was an effective chemokine produced in kidney cells during acute ischemic and toxic renal damage. Several previous studies have shown that expression of MCP-1 protein and mRNA was greater than NGAL in renal damage. In prerenal and postrenal injury, elevated level of NGAL corresponded to MCP-1 gene expression [143]. Other studies proved that uremia, in the absence of renal injury, induced the NGAL gene, but not MCP-1, which supports the specificity of MCP-1 in AKI diagnosis [143].

Soluble triggering receptor expressed on myeloid cells-1 (sTREM-1)

sTREM-1 plays an important role in sepsis diagnosis and prediction of sepsis-associated AKI. It has been demonstrated that urine sTREM-1 is a risk factor for AKI occurrence in sepsis patients. However, the mechanisms of sTREM-1 involvement in AKI have not been clearly demonstrated. In addition to systemic inflammation, local inflammatory response in the kidney can also help to increase urinary sTREM-1 secretion. To further evaluate the role of sTREM-1 in this process, Su L et al [144] conducted a larger cohort multicenter study to reveal the diagnostic value and mechanism of sTREM-1 during sepsis-associated AKI process. The research is currently ongoing, and if successful, urine sTREM-1 could be a good marker for sepsis and its associated AKI and could contribute to noninvasive diagnosis and monitoring in the clinical setting. 


\section{Kidney \\ Blood Pressure Research}

Table 1. Promising biomarkers undergoing clinical evaluation in AKI

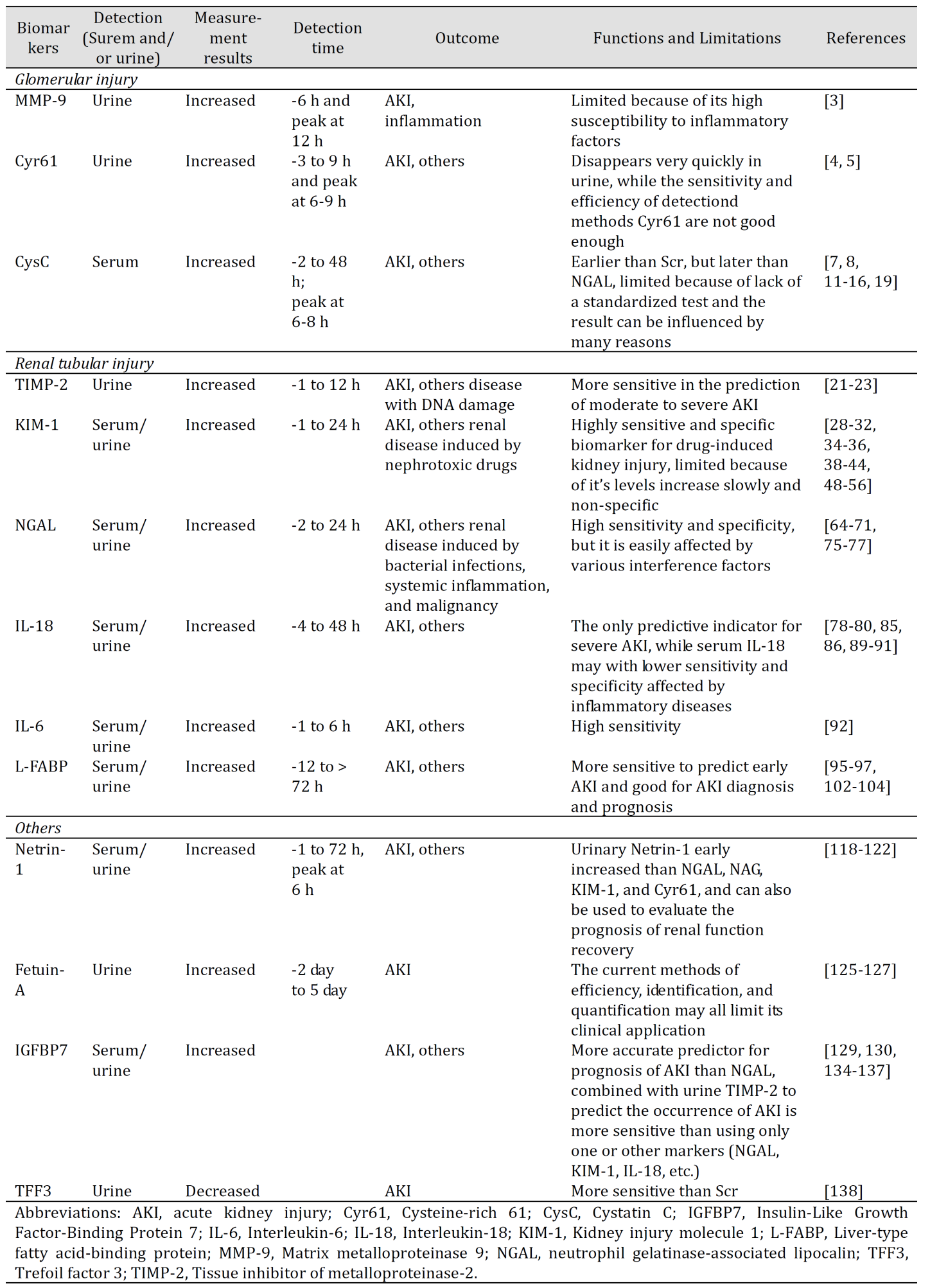

\section{Conclusion}

The discovery of the above-described biological markers has shed more light on the early diagnosis and treatment of AKI (Summized in Table 1), while some of them, such as 


\section{Kidney \\ Blood Pressure Research}

NAG and CysC, have entered clinical application. They provide an important basis for early monitoring of AKI, but there are still some problems and shortcomings. An ideal biological marker should include the following advantages: First, they should reflect early kidney damage and the degree. Second, the cause of renal injury should be distinguishable. Third, they should help in assessing the location of renal injury. Fourth, they should reflect the prognosis of kidney injury. Fifth, the detection method must be rapid and convenient. Only with these characteristics can a biological marker be helpful for early diagnosis, early intervention, targeted therapy, and therapeutic monitoring of AKI, thereby reducing morbidity and mortality. The etiological factors and pathogenesis of AKI are diverse and complex, and combinational detection of different markers is needed to achieve the expected purpose. Therefore, future studies are necessary to explore an effective combination of detection factors to identify a more effective method for the prevention and treatment of AKI.

\section{Disclosure Statement}

The authors of this manuscript state that they do not have any conflict of interests and nothing to disclose.

\section{References}

1 Clinical Practice Guidelines for Acute Kidney Injury 2012. http://www.kdigo.org/clinical_practice_ guidelines/AKI.php.

2 Lameire N, Van Biesen W, Vanholder R: Acute takes failure. Lancet 2005;365:417-430.

3 Qian J, Fang J, Zhu Q, Ma S, Wang W, Zheng Y, Hao G, Deng B, Zhao X, Ding F: Serum protein thiol levels in patients with hospital-acquired acute kidney injury. Kidney Blood Press Res 2015;40:623-629.

4 Han WK, Waikar SS, Johnson A, Betensky RA, Dent CL, Devarajan P, Bonventre JV: Urinary biomarkers in the early diagnosis of acute kidney injury. Kidney Int 2008;73:863-869.

5 Muramatsu Y, Tsujie M, Kohda Y, Pham B, Perantoni AO, Zhao H, Jo SK, Yuen PS, Craig L, Hu X, Star RA: Early detection of cysteine rich protein 61 (cyr61, ccn1) in urine following renal ischemic reperfusion injury. Kidney Int 2002;62:1601-1610.

6 Sawai K, Mukoyama M, Mori K, Kasahara M, Koshikawa M, Yokoi H, Yoshioka T, Ogawa Y, Sugawara A, Nishiyama H, Yamada S, Kuwahara T, Saleem MA, Shiota K, Ogawa O, Miyazato M, Kangawa K, Nakao K: Expression of ccn1 (cyr61) in developing, normal, and diseased human kidney. Am J Physiol Renal Physiol 2007;293:F1363-1372.

7 Groesbeck D, Kottgen A, Parekh R, Selvin E, Schwartz GJ, Coresh J, Furth S: Age, gender, and race effects on cystatin c levels in us adolescents. Clin J Am Soc Nephrol 2008;3:1777-1785.

8 Peco-Antic A, Ivanisevic I, Vulicevic I, Kotur-Stevuljevic J, Ilic S, Ivanisevic J, Miljkovic M, Kocev N: Biomarkers of acute kidney injury in pediatric cardiac surgery. Clin Biochem 2013;46:1244-1251.

9 Krawczeski CD, Goldstein SL, Woo JG, Wang Y, Piyaphanee N, Ma Q, Bennett M, Devarajan P: Temporal relationship and predictive value of urinary acute kidney injury biomarkers after pediatric cardiopulmonary bypass. J Am Coll Cardiol 2011;58:2301-2309.

10 Haase-Fielitz A, Bellomo R, Devarajan P, Story D, Matalanis G, Dragun D, Haase M: NoveI and conventionalserum biomarkers predicting acute kidney injury in adult cardiac surgery-a prospective cohort study. Crit Care Med 2009;37:553-560.

11 Krawczeski CD, Vandevoorde RG, Kathman T, Bennett MR, Woo JG, Wang Y, Griffiths RE, Devarajan P: Serum cystatin $\mathrm{C}$ is an early predictive biomarker of acute kidney inj ury after pediatric cardiopulmonary bypass. Clin J Am Soc Nephrol 2010;5:1552-1557.

12 Bachorzewska-Gajewska H, Malyszko J, Sitniewska E, Malyszko JS, Poniatowski B, Pawlak K, Dobrzycki S: NGAL (neutrophil gelatinase-associated lipocalin) and cystatin c: Are they good predictors of contrast nephropathy after percutaneous coronary interventions in patients with stable angina and normal serum creatinine? Int J Cardiol 2008;127:290-291.

13 Herget-Rosenthal S, Marggraf G, Husing J, Goring F, Pietruck F, Janssen O, Philipp T, Kribben A: Early detection of acute renal failure by serum cystatin c. Kidney Int 2004;66:1115-1122. 


\section{Kidney \\ Blood Pressure Research}

14 Asilioglu N, Acikgoz Y, Paksu MS, Gunaydin M, Ozkaya O: Is serum cystatin C a better marker than serum creatinine for monitoring renal function in pediatric intensive care unit? J Trop Pediatr 2012;58:429-434.

15 Ling W, Zhaohui N, Ben H, Leyi G, Jianping Liu, Huili D, Jiaqi Q: Urinary IL-18 and NGAL as early predictive biomarkers in contrast-induced nephropathy after coronary angiography. Nephron Clin Pract 2008;108:176-181.

16 Al-Beladi FI: Cystatin C is an early marker of contrast-induced nephropathy in patients with sepsis in the intensive care unit. Saudi J Kidney Dis Transpl 2015;26:718-724.

17 Uzun H, Ozmen Keles M, Ataman R, Aydin S, Kalender B, Uslu E, Simsek G, Halac M, Kaya S: Serum cystatin c level as a potentially good marker for impaired kidney function. Clin Biochem 2005;38:792-798.

18 Dharnidharka VR, Kwon C, Stevens G: Serum cystatinC is superior to serum creatinine as a marker of kidneyfunction: a meta-analysis. Am J Kidney Dis 2002;40:221-226.

19 Chen S, Shi JS, Yibulayin X, Wu TS, Yang XW, Zhang J, Baiheti P: Cystatin C is a moderate predictor of acute kidney injury in the early stage of traumatic hemorrhagic shock. Exp Ther Med 2015;10:237-240.

20 Knight EL, Verhave JC, Spiegelman D, Hillege HL, de Zeeuw D, Curhan GC, de Jong PE: Factors influencing serum cystatin $\mathrm{C}$ levels other than renal function and the impact on renal function measurement. Kidney Int 2004;65:1416-1421.

21 Stetler-Stevenson WG: Tissue inhibitors of metalloproteinases in cell signaling: metalloproteinaseindependent biological activities. Sci Signal 2008;1:re6.

22 Sulikowski T, Domanski L, Zietek Z, Adler G, Pawlik A, Ciechanowicz A, Ciechanowski K, Ostrowski M: Effect of preservation solutions UW and EC on the expression of matrix metalloproteinase II and tissue inhibitor of metalloproteinase II genes in rat kidney. Postepy Hig Med Dosw (Online) 2012;66:45-50.

23 Jiang Z, Sui T, Wang B: Relationships between MMP-2, MMP-9, TIMP-1 and TIMP-2 levels and their pathogenesis in patients with lupus nephritis. Rheumatol Int 2010;30:1219-1226.

24 Kashani K, Al-Khafaji A, Ardiles T, Artigas A, Bagshaw SM, Bell M, Bihorac A, Birkhahn R, Cely CM, Chawla LS, Davison DL, Feldkamp T, Forni LG, Gong MN, Gunnerson KJ, Haase M, Hackett J, Honore PM, Hoste EA, Joannes-Boyau O, Joannidis M, Kim P, Koyner JL, Laskowitz DT, Lissauer ME, Marx G, McCullough PA, Mullaney S, Ostermann M, Rimmele T, Shapiro NI, Shaw AD, Shi J, Sprague AM, Vincent JL, Vinsonneau C, Wagner L, Walker MG, Wilkerson RG, Zacharowski K, Kellum JA: Discovery and validation of cell cycle arrest biomarkers in human acute kidney injury. Crit Care 2013;17:R25.

25 Cruz DN, Goh CY, Haase-Fielitz A, Ronco C, Haase M: Early biomarkers of renal injury. Congest Heart Fail 2010;16:S25-31.

26 Vaidya VS, Waikar SS, Ferguson MA, Collings FB, Sunderland K, Gioules C, Bradwin G, Matsouaka R, Betensky RA, Curhan GC, Bonventre JV: Urinary biomarkers for sensitive and specific detection of acute kidney injury in humans. Clin Transl Sci 2008;1:200-208.

27 Han WK, Bailly V, Abichandani R, Thadhani R, Bonventre JV: Kidney injury molecule-1 (kim-1): A novel biomarker for human renal proximal tubule injury. Kidney Int 2002;62:237-244.

28 Kramer AB, van Timmeren MM, Schuurs TA, Vaidya VS, Bonventre JV, van Goor H, Navis G: Reduction of proteinuria in adriamycin-induced nephropathy is associated with reduction of renal kidney injury molecule (kim-1) over time. Am J Physiol 2009;296:F1136-1145.

29 Sabbisetti VS, Waikar SS, Antoine DJ, Smiles A, Wang C, Ravisankar A, Ito K, Sharma S, Ramadesikan S, Lee M, Briskin R, De Jager PL, Ngo TT, Radlinski M, Dear JW, Park KB, Betensky R, Krolewski AS, Bonventre JV: Blood kidney injury molecule-1 is a biomarker of acute and chronic kidney injury and predicts progression to ESRD in type I diabetes. J Am Soc Nephrol 2014;25:2177-2186.

30 Kadioglu T, Uzunlulu M, Yigit Kaya S, Oguz A, Gonenli G, Isbilen B, Isman FK: Urinary kidney injury molecule-1 levels as a marker of early kidney injury in hypertensive patients. Minerva Urol Nefrol 2015 [Epub ahead of print].

31 Lim AI, Tang SC, Lai KN, Leung JC: Kidney injury molecule -1, more than just an injury marker of tubular epithelial cells? J Cell Physiol 2013;228:917-924.

32 Vaidya VS, Ferguson MA, Bonventre JV: Biomarkers of acute kidney injury. Annu Rev Pharmacol Toxicol 2008;48:463-493.

33 Slocum JL, Heung M, Pennathur S: Marking renal injury: Can we move beyond serum creatinine? Transl Res 2012;159:277-289.

34 Akdeniz D, Celik HT, Kazanci F, Yilmaz H, Yalcin S, Bilgic MA, Ruzgaresen N, Akcay A, Eryonucu B: Is Kidney Injury Molecule 1 a Valuable Tool for the Early Diagnosis of Contrast-Induced Nephropathy? J Investig Med 2015;63:930-934. 


\section{Kidney \\ Blood Pressure Research}

35 Li W, Yu Y, He H, Chen J, Zhang D: Urinary kidney injury molecule-1 as an early indicator to predict contrast-induced acute kidney injury in patients with diabetes mellitus undergoing percutaneous coronary intervention. Biomed Rep 2015;3:509-512.

36 Perco P, Oberbauer R: Kidney injury molecule-1 as a biomarker of acute kidney injury in renal transplant recipients. Nat Clin Pract Nephrol 2008;4:362-363.

37 Huang Y, Don-Wauchope AC: The clinical utility of kidney injury molecule 1 in the prediction, diagnosis and prognosis of acute kid ney injury: A systematic review. Inflamm Allergy Drug Targets 2011;10:260-271.

38 Zhang J, Goering PL, Espandiari P, Shaw M, Bonventre JV, Vaidya VS, Brown RP, Keenan J, Kilty CG, Sadrieh N, Hanig JP: Differences in immunolocalization of kim-1, rpa-1, and rpa-2 in kidneys of gentamicin-, cisplatin-, and valproic acid-treated rats: Potential role of inos and nitrotyrosine. Toxicol Pathol 2009;37:629-643.

39 Vaidya VS, Ozer JS, Dieterle F, Collings FB, Ramirez V, Troth S, Muniappa N, Thudium D, Gerhold D, Holder DJ, Bobadilla NA, Marrer E, Perentes E, Cordier A, Vonderscher J, Maurer G, Goering PL, Sistare FD, Bonventre JV: Kidney injury molecule-1 outperforms traditional biomarkers of kidney injury in preclinical biomarker qualification studies. Nat Biotechnol 2010;28:478-485.

40 Ichimura T, Hung CC, Yang SA, Stevens JL, Bonventre JV: Kidney injury molecule-1: A tissue and urinary biomarker for nephrotoxicant-induced renal injury. Am J Physiol Renal Physiol 2004;286:F552-563.

41 van Timmeren MM, van den Heuvel MC, Bailly V, Bakker SJ, van Goor H, Stegeman CA: Tubular kidney injury molecule-1 (kim-1) in human renal disease. J Pathol 2007;212:209-217.

42 Xie HG, Wang SK, Cao CC, Harpur E: Qualified kidney biomarkers and their potential significance in drug safety evaluation and prediction. Pharmacol Ther 2013;137:100-107.

43 Genc G, Ozkaya O, Avci B, Aygun C, Kucukoduk S: Kidney injury molecule-1 as a promising biomarker for acute kidney injury in premature babies. Am J Perinatol 2013;30:245-252.

44 Liangos O, Perianayagam MC, Vaidya VS, Han WK, Wald R, Tighiouart H, MacKinnon RW, Li L, Balakrishnan VS, Pereira BJ, Bonventre JV, Jaber BL: Urinary n-acetyl-beta-(d)-glucosaminidase activity and kidney injury molecule-1 level are associated with adverse outcomes in acute renal failure. J Am Soc Nephrol 2007;18:904-912.

45 Han WK, Waikar SS, Johnson A, Betensky RA, Dent CL, Devarajan P, Bonventre JV: Urinary biomarkers in the early diagnosis of acute kidney injury. Kidney Int 2008;73:863-869.

46 Bonventre JV, Vaidya VS, Schmouder R, Feig P, Dieterle F: Next-generation biomarkers for detecting kidney toxicity. Nat Biotechnol 2010;28:436-440.

47 Medic B, Rovcanin B, Basta Jovanovic G, Radojevic-Skodric S, Prostran M: Kidney injury molecule-1 and cardiovascular diseases: From basic science to clinical practice. Biomed Res Int 2015;2015:854070.

48 Chaturvedi S, Farmer T, Kapke GF: Assay validation for kim-1: Human urinary renal dysfunction biomarker. Int J Biol Sci 2009;5:128-134.

49 Ichimura T, Asseldonk EJ, Humphreys BD, Gunaratnam L, Duffield JS, Bonventre JV: Kidney injury molecule-1 is a phosphatidy lserine receptor that confers a phagocytic phenotype on epithelial cells. J Clin Invest 2008;118:1657-1668.

50 Zhang PL, Rothblum LI, Han WK, Blasick TM, Potdar S, Bonventre JV: Kidney injury molecule-1 expression in transplant biopsies is a sensitive measure of cell injury. Kidney Int 2008;73:608-614.

51 Ko GJ, Grigoryev DN, Linfert D, Jang HR, Watkins T, Cheadle C, Racusen L, Rabb H: Transcriptional analysis of kidneys during repair from aki reveals possible roles for ngal and kim-1 as biomarkers of aki-to-ckd transition. Am J Physiol Renal Physiol 2010;298:F1472-1483.

52 Tonomura Y, Tsuchiya N, Torii M, Uehara T: Evaluation of the usefulness of urinary biomarkers for nephrotoxicity in rats. Toxicology 2010;273:53-59.

53 Bonventre JV: Kidney injury molecule -1 (kim-1): A urinary biomarker and much more. Nephrol Dial Transplant 2009;24:3265-3268.

54 Huo W, Zhang K, Nie Z, Li Q, Jin F: Kidney injury molecule-1 (kim-1): A novel kidney-specific injury molecule playing potential double-edged functions in kidney injury. Transplant Rev 2010;24:143-146.

55 Sabbisetti VS, Ito K, Wang C, Yang L, Mefferd SC, Bonventre JV: Novel assays for detection of urinary kim-1 in mouse models of kidney injury. Toxicol Sci 2013;131:13-25.

56 Dieterle F, Sistare F, Goodsaid F, Papaluca M, Ozer JS, Webb CP, Baer W, Senagore A, Schipper MJ, Vonderscher J, Sultana S, Gerhold DL, Phillips JA, Maurer G, Carl K, Laurie D, Harpur E, Sonee M, Ennulat D, Holder D, Andrews-Cleavenger D, Gu YZ, Thompson KL, Goering PL, Vidal JM, Abadie E, Maciulaitis R, Jacobson-Kram D, Defelice AF, Hausner EA, Blank M, Thompson A, Harlow P, Throckmorton D, Xiao S, Xu N, Taylor W, Vamvakas S, Flamion B, Lima BS, Kasper P, Pasanen M, Prasad K, Troth S, Bounous D, RobinsonGravatt D, Betton G, Davis MA, Akunda J, McDuffie JE, Suter L, Obert L, Guffroy M, Pinches M, Jayadev S, 


\section{Kidney \\ Blood Pressure Research}

Blomme EA, Beushausen SA, Barlow VG, Collins N, Waring J, Honor D, Snook S, Lee J, Rossi P, Walker E, Mattes W: Renal biomarker qualification submission: A dialog between the fda-emea and predictive safety testing consortium. Nat Biotechnol 2010;28:455-462.

57 Bonventre JV: Kidney injury molecule-1 (kim-1): A specific and sensitive biomarker of kidney injury. Scand J Clin Lab Invest Suppl 2008;241:78-83.

58 Basnakian AG: Netrin-1: A potential universal biomarker for acute kidney injury. Am J Physiol Renal Physiol 2008;294:F729-730.

59 Kjeldsen L, Johnsen AH, Sengelov H, Borregaard N: Isolation and primary structure of ngal, a novel protein associated with human neutrophil gelatinase. J Biol Chem 1993;268:10425-10432.

60 Malyszko J: Biomarkers of acute kidney injury in different clinical settings: a time to change the paradigm. Kidney Blood Press Res 2010;33:368-382.

61 Cowland JB, Sorensen OE, Sehested M: Neutrophil gelatinase-associated lipocalin is up-regulated in human epithelial cells by IL-1 beta, but not by TNF-alpha. J Immunol 2003;171:6630-6639.

62 Sanjeevani S, Pruthi S, Kalra S, Goel A, Kalra OP: Role of neutrophil gelatinase-associated lipocalin for early detection of acute kidney injury. Int J Crit Illn Inj Sci 2014;4:223-228.

63 Haase M, Bellomo R, Devarajan P, Schlattmann P, Haase-Fielitz A, Group NM-aI: Accuracy of neutrophil gelatinase-associated lipocalin (NGAL) in diagnosis and prognosis in acute kidney injury: A systematic review and meta-analysis. Am J Kidney Dis 2009;54:1012-1024.

64 Taghizadeh-Ghehi M, Sarayani A, Ashouri A, Ataei S, Moslehi A, Hadjibabaie M: Urine neutrophil gelatinase associated lipocalin as an early marker of acute kidney injury in hematopoietic stem cell transplantation patients. Ren Fail 2015;37:994-998.

65 Kim JD, Chee HK, Shin JK, Kim JS, Lee SA, Kim YH, Lee WS, Kim HY: Novel early predictor of acute kidney injury after open heart surgery under cadiopulmonary bypass using plasma neutrophil gelatinaseassociated lipocalin. Korean J Thorac Cardiovasc Surg 2014;47:240-248.

66 Kidher E, Harling L, Ashrafian H, Naase H, Chukwuemeka A, Anderson J, Francis DP, Athanasiou T: Pulse wave velocity and neutrophil gelatinase-associated lipocalin as predictors of acute kidney injury following aortic valve replacement. J Cardiothorac Surg 2014;9:89.

67 Arun O, Celik G, Oc B, Unlu A, Celik JB, Oc M, Duman A: Renal effects of coronary artery bypass graft surgery in diabetic and non-diabetic patients: a study with urinary neutrophil gelatinase-associated lipocalin and serum cystatin C. Kidney Blood Press Res 2015;40:141-52.

68 Lin F, Zhang PL, Yang XJ, Shi J, Blasick T, Han WK, Wang HL, Shen SS, Teh BT, Bonventre JV: Human kidney injury molecule-1 (hkim-1): A useful immunohistochemical marker for diagnosing renal cell carcinoma and ovarian clear cell carcinoma. Am J Surg Pathol 2007;31:371-381.

69 Sen S, Godwin ZR, Palmieri T, Greenhalgh D, Steele AN, Tran NK: Whole blood neutrophil gelatinaseassociated lipocalin predicts acute kidney injury in burn patients. J Surg Res 2015;196:382-387.

70 Surmiak P, Baumert M, Fiala M, Walencka Z, Wiecek A: Umbilical neutrophil gelatinase-associated lipocalin level as an early predictor of acute kidney injury in neonates with hypoplastic left heart syndrome. Biomed Res Int 2015;2015:360209.

71 Makris K, Markou N, Evodia E, Dimopoulou E, Drakopoulos I, Ntetsika K, Rizos D, Baltopoulos G, Haliassos A: Urinary neutrophil gelatinase-associated lipocalin (NGAL) as an early marker of acute kidney injury in critically ill multiple trauma patients. Clin Chem Lab Med 2009;47:79-82.

72 Iguchi N, Uchiyama A, Ueta K, Sawa Y, Fujino Y: Neutrophil gelatinase-associated lipocalin and liver-type fatty acid-binding protein as biomarkers for acute kidney injury after organ transplantation. J Anesth 2015;29:249-255.

73 Shahbazi F, Sadighi S, Dashti-Khavidaki S, Shahi F, Mirzania M: Urine ratio of neutrophil gelatinaseassociated lipocalin to creatinine as a marker for early detection of cisplatin-associated nephrotoxicity. Iran J Kidney Dis 2015;9:306-310.

74 Seker MM, Deveci K, Seker A, Sancakdar E, Yilmaz A, Turesin AK, Kacan T, Babacan NA: Predictive role of neutrophil gelatinase-associated lipocalin in early diagnosis of platin-induced renal injury. Asian Pac J Cancer Prev 2015;16:407-410.

75 Tsuchimoto A, Shinke H, Uesugi M, Kikuchi M, Hashimoto E, Sato T, Ogura Y, Hata K, Fujimoto Y, Kaido T, Kishimoto J, Yanagita M, Matsubara K, Uemoto S, Masuda S: Urinary neutrophil gelatinase-associated lipocalin: A useful biomarker for tacrolimus-induced acute kidney injury in liver transplant patients. PloS One 2014;9:e110527. 


\section{Kidney \\ Blood Pressure Research}

76 Quintavalle C, Anselmi CV, De Micco F, Roscigno G, Visconti G, Golia B, Focaccio A, Ricciardelli B, Perna E, Papa L, Donnarumma E, Condorelli G, Briguori C: Neutrophil gelatinase-associated lipocalin and contrastinduced acute kidney injury. Circ Cardiovasc Interv 2015;8:e002673.

77 Martensson J, Bell M, Oldner A, Xu S, Venge P, Martling CR: Neutrophil gelatinase-associated lipocalin in adult septic patients with and without acute kidney injury. Intensive Care Med 2010;36:1333-1340.

78 Vanmassenhove J, Glorieux G, Lameire N, Hoste E, Dhondt A, Vanholder R, Van Biesen W: Influence of severity of illness on neutrophil gelatinase-associated lipocalin performance as a marker of acute kidney injury: A prospective cohort study of patients with sepsis. BMC Nephrol 2015;16:18.

79 Hawkins R: New biomarkers of acute kidney injury and the cardiorenal syndrome. Korean J Lab Med 2011;31:72-80.

80 Helanova K, Spinar J, Parenica J: Diagnostic and prognostic utility of neutrophil gelatinase-associated lipocalin (NGAL) in patients with cardiovascular diseases-review. Kidney Blood Press Res 2014;39:623629.

81 Parikh CR, Abraham E, Ancukiewicz M, Edelstein CL: Urine il-18 is an early diagnostic marker for acute kidney injury and predicts mortality in the intensive care unit. J Am Soc Nephrol 2005;16:3046-3052.

82 Parikh CR, Mishra J, Thiessen-Philbrook H, Dursun B, Ma Q Kelly C, Dent C, Devarajan P, Edelstein CL: Urinary il-18 is an early predictive biomarker of acute kidney injury after cardiac surgery. Kidney Int 2006;70:199-203.

83 Parikh CR, Devarajan P, Zappitelli M, Sint K, Thiessen-Philbrook H, Li S, Kim RW, Koyner JL, Coca SG, Edelstein CL, Shlipak MG, Garg AX, Krawczeski CD, Consortium T-A: Postoperative biomarkers predict acute kidney injury and poor outcomes after pediatric cardiac surgery. J Am Soc Nephrol 2011;22:1737-1747.

84 Barrantes F, Tian J, Vazquez R, Amoateng-Adjepong Y, Manthous CA: Acute kidney injury criteria predict outcomes of critically ill patients. Crit Care Med 2008;36:1397-1403.

85 Siew ED, Ikizler TA, Gebretsadik T, Shintani A, Wickersham N, Bossert F, Peterson JF, Parikh CR, May AK, Ware LB: Elevated urinary il-18 levels at the time of icu admission predict adverse clinical outcomes. Clin J Am Soc Nephrol 2010;5:1497-1505.

86 Washburn KK, Zappitelli M, Arikan AA, Loftis L, Yalavarthy R, Parikh CR, Edelstein CL, Goldstein SL: Urinary interleukin-18 is an acute kidney injury biomarker in critically ill children. Nephrol Dial Transplant 2008;23:566-572.

87 Hall IE, Yarlagadda SG, Coca SG, Wang Z, Doshi M, Devarajan P, Han WK, Marcus RJ, Parikh CR: Il-18 and urinary ngal predict dialysis and graft recovery after kidney transplantation. J Am Soc Nephrol 2010;21:189-197.

88 Liangos O, Tighiouart H, Perianayagam MC, Kolyada A, Han WK, Wald R, Bonventre JV, Jaber BL: Comparative analysis of urinary biomarkers for early detection of acute kidney injury following cardiopulmonary bypass. Biomarkers 2009;14:423-431.

89 Haase M, Bellomo R, Story D, Davenport P, Haase-Fielitz A: Urinary interleukin-18 does not predict acute kidney injury after adult cardiac surgery: A prospective observational cohort study. Crit Care 2008;12:R96.

90 Parikh CR, Devarajan P: New biomarkers of acute kidney injury. Crit Care Med 2008;36:S159-S165.

91 Liu Y, Guo W, Zhang J, Xu C, Yu S, Mao Z, Wu J, Ye C, Mei C, Dai B: Urinary interleukin 18 for detection of acute kidney injury: A meta-analysis. Am J Kidney Dis 2013;62:1058-1067.

92 Vaidya VS, Ferguson MA, Bonventre JV: Biomarkers of acute kidney injury. Ann Rev Pharmacol Toxicol 2008;1:463.

93 Obermuller N, Geiger H, Weipert C, Urbschat A: Current developments in early diagnosis of acute kidney injury. Int Urol Nephrol 2014;46:1-7.

94 Leslie JA, Meldrum KK: The role of interleukin-18 in renal injury. J Surg Res 2008;145:170-175.

95 Dennen P, Altmann C, Kaufman J, Klein CL, Andres-Hernando A, Ahuja NH, Edelstein CL, Cadnapaphornchai MA, Keniston A, Faubel S: Urine interleukin-6 is an early biomarker of acute kidney injury in children undergoing cardiac surgery. Crit Care 2010;14:R181.

96 Wohlfahrtova M, Tycova I, Honsova E, Lodererova A, Viklicky O: Molecular patterns of subclinical and clinical rejection of kidney allograft: quantity matters. Kidney Blood Press Res 2015;40:244-257.

97 Manabe K, Kamihata H, Motohiro M, Senoo T, Yoshida S, Iwasaka T: Urinary liver-type fatty acid-binding protein level as a predictive biomarker of contrast-induced acute kidney injury. Eur J Clin Invest 2012;42:557-563.

98 Kamijo A, Sugaya T, Hikawa A, Yamanouchi M, Hirata Y, Ishimitsu T, Numabe A, Takagi M, Hayakawa H, Tabei F, Sugimoto T, Mise N, Omata M, Kimura K: Urinary liver-type fatty acid binding protein as a useful biomarker in chronic kidney disease. Mol Cell Biochem 2006;284:175-182. 


\section{Kidney \\ Blood Pressure Research}

99 Matsui K, Kamijo-Ikemori A, Sugaya T, Yasuda T, Kimura K: Usefulness of urinary biomarkers in early detection of acute kidney injury after cardiac surgery in adults. Circ J 2012;76:213-220.

100 Ivanisevic I, Peco-Antic A, Vulicevic I, Hercog D, Milovanovic V, Kotur-Stevuljevic J, Stefanovic A, Kocev N: L-fabp can be an early marker of acute kidney injury in children. Pediatr Nephrol 2013;28:963-969.

101 Cho E, Yang HN, Jo SK, Cho WY, Kim HK: The role of urinary liver-type fatty acid-binding protein in critically ill patients. J Korean Med Sci 2013;28:100-105.

102 Portilla D, Dent C, Sugaya T, Nagothu KK, Kundi I, Moore P, Noiri E, Devarajan P: Liver fatty acid-binding protein as a biomarker of acute kidney injury after cardiac surgery. Kidney Int 2008;73:465-472.

103 Shingai N, Morito T, Najima Y, Igarashi A, Kobayashi T, Doki N, Kakihana K, Ohashi K, Ando M: Urinary livertype fatty acid-binding protein linked with increased risk of acute kidney injury after allogeneic stem cell transplantation. Biol Blood Marrow Transplant 2014;20:2010-2014.

104 Xin C, Yulong X, Yu C, Changchun C, Feng Z, Xinwei M: Urine neutrophil gelatinase-associated lipocalin and interleukin-18 predict acute kidney injury after cardiac surgery. Ren Fail 2008;30:904-913.

105 Noiri E, Doi K, Negishi K, Tanaka T, Hamasaki Y, Fujita T, Portilla D, Sugaya T: Urinary fatty acid-binding protein 1: An early predictive biomarker of kidney injury. Am J Physiol Renal Physiol 2009;296:F669-679.

106 Negishi K, Noiri E, Sugaya T, Li S, Megyesi J, Nagothu K, Portilla D: A role of liver fatty acid-binding protein in cisplatin-induced acute renal failure. Kidney Int 2007;72:348-358.

107 Hiruma T, Asada T, Yamamoto M, Inokuchi R, Matsubara T, Ishii T, Sumida M, Isshiki R, Mayumi K, Noiri E, Nangaku M, Yahagi N, Doi K: Mortality prediction by acute kidney injury biomarkers in comparison with serum creatinine. Biomarkers 2014;19:646-651.

108 Susantitaphong P, Siribamrungwong M, Doi K, Noiri E, Terrin N, Jaber BL: Performance of urinary liver-type fatty acid-binding protein in acute kidney injury: A meta-analysis. Am J Kidney Dis 2013;61:430-439.

109 du Cheyron D, Daubin C, Poggioli J, Ramakers M, Houillier P, Charbonneau P, Paillard M: Urinary measurement of na+/h+ exchanger isoform 3 (nhe3) protein as new marker of tubule injury in critically ill patients with arf. Am J Kidney Dis 2003;42:497-506.

110 Nakajima Y, Hoshi F, Higuchi S, Kawamura S: Determination of canine beta2-microgloblin in plasma and urine by enzyme-linked immunosorbent assay. J Vet Med Sci 2001;63:343-345.

111 Roberts DS, Haycock GB, Dalton RN, Turner C, Tomlinson P, Stimmler L, Scopes JW: Prediction of acute renal failure after birth asphyxia. Arch Dis Child 1990;65:1021-1028.

112 Hidaka S, Kranzlin B, Gretz N, Witzgall R: Urinary clusterin levels in the rat correlate with the severity of tubular damage and may help to differentiate between glomerular and tubular injuries. Cell Tissue Res 2002;310:289-296.

113 Ishii A, Sakai Y, Nakamura A: Molecular pathological evaluation of clusterin in a rat model of unilateral ureteral obstruction as a possible biomarker of nephrotoxicity. Toxicol Pathol 2007;35:376-382.

114 Ye M, Xie X, Peng L, Tan L, Lan G, Yu S: expression and mechanism of osteoactivin in the kidney of sd rats after acute cyclosporine a toxicity. J Cent South Univ 2011;36:881-888.

115 Westhuyzen J, Endre ZH, Reece G, Reith DM, Saltissi D, Morgan TJ: Measurement of tubular enzymuria facilitates early detection of acute renal impairment in the intensive care unit. Nephrol Dial Transplant 2003;18:543-551.

116 Vaidya VS, Ramirez V, Ichimura T, Bobadilla NA, Bonventre JV: Urinary kidney injury molecule-1: A sensitive quantitative biomarker for early detection of kidney tubular injury. Am J Physiol Renal Physiol 2006;290:F517-529.

117 Fujita H, Narita T, Morii T, Shimotomai T, Yoshioka N, Kakei M, Ito S: Increased urinary excretion of n-acetylglucosaminidase in subjects with impaired glucose tolerance. Renal Fail 2002;24:69-75.

118 Lorenzen JM, Schauerte C, Kielstein JT, Hübner A, Martino F, Fiedler J, Gupta SK, Faulhaber-Walter R, Kumarswamy R, Hafer C, Haller H, Fliser D, Thum T: Circulating long noncoding RNATapSaki is a predictor of mortality in critically ill patients with acute kidney injury. Clin Chem 2015;61:191-201.

119 Gutiérrez-Escolano A, Santacruz-Vázquez E, Gómez-Pérez F: Dysregulated microRNAs involved in contrastinduced acute kidney injury in rat and human. Ren Fail 2015;37:1498-506.

120 Bradford D, Cole SJ, Cooper HM: Netrin-1: diversity in devel opment. Int J Biochem Cell Biol 2009;41:487493.

121 Urbschat A, Obermuller N, Haferkamp A: Biomarkers of kidney injury. Biomarkers 2011;16:S22-S30.

122 Wang W, Reeves WB, Ramesh G: Netrin-1 and kidney injury. I. Netrin-1 protects against ischemiareperfusion injury of the kidney. Am J Physiol Renal Physiol 2008;294:F739-F747.

123 Wang W, Reeves WB, Pays L, Mehlen P, Ramesh G: Netrin-1 overexpression protects kidney from ischemia reperfusion injury by suppressing apoptosis. Am J Pathol 2009;175:1010-1018. 


\section{Kidney \\ Blood Pressure Research}

Liu et al.: Early Predictors for AKI

124 Ramesh G, Krawczeski CD, Woo JG, Wang Y, Devarajan P: Urinary netrin-1 is an early predictive biomarker of acute kidney injury after cardiac surgery. Clin J Am Soc Nephrol 2010;5:395-401.

125 Reeves WB, Kwon O, Ramesh G: Netrin-1 and kidney injury. II . Netrin-1 is an early biomarker of acute kidney injury. Am J Physiol Renal Physiol 2008;294:F731-F738.

126 Wohlfahrtova M, Brabcova I, Zelezny F, Balaz P, Janousek L, Honsova E, Lodererova A, Wohlfahrt P, Viklicky O: Tubular atrophy and low netrin-1 gene expression are associated with delayed kidney allograft function. Transplantation 2014;97:176-183.

127 Tak E, Ridyard D, Badulak A, Giebler A, Shabeka U, Werner T, Clambey E, Moldovan R, Zimmerman MA, Eltzschig HK, Grenz A: Protective role for netrin-1 during diabetic nephropathy. J Mol Med (Berl) 2013;91:1071-1080.

128 Ramesh G, Kwon 0, Ahn K: Netrin-1: a novel universal biomarker of human kidney injury. Transplant Proc 2010;42:1519-1522.

129 Zhou H, Pisitkun T, Aponte A, Yuen PS, Hoffert JD, Yasuda H, Hu X, Chawla L, Shen RF, Knepper MA, Star RA: Exosomal fetuin-a identified by proteomics: A novel urinary biomarker for detecting acute kidney injury. Kidney Int 2006;70:1847-1857.

130 Cheruvanky A, Zhou H, Pisitkun T, Kopp JB, Knepper MA, Yuen PS, Star RA: Rapid isolation of urinary exosomal biomarkers using a nanomembrane ultrafiltration concentrator. Am J Physiol Renal Physiol 2007;292:F1657-1661.

131 Ono Y, Hashimoto T, Umeda F, Masakado M, Yamauchi T, Mizushima S, Isaji M, Nawata H: Expression of prostacyclin-stimulating factor, a novel protein, in tissues of wistar rats and in cultured cells. Biochem Biophys Res Commun 1994;202:1490-1496.

132 Swisshelm K, Ryan K, Tsuchiya K, Sager R: Enhanced expression of an insulin growth factor-like binding protein (mac25) in senescent human mammary epithelial cells and induced expression with retinoic acid. Proc Natl Acac Sci USA 1995;92:4472-4476.

133 Degeorges A, Wang F, Frierson HF Jr, Seth A, Sikes RA: Distribution of igfbp-rp1 in normal human tissues. Histochem Cytochem 2000;48:747-754.

134 Lopez-Bermejo A, Khosravi J, Corless CL, Krishna RG, Diamandi A, Bodani U, Kofoed EM, Graham DL, Hwa V, Rosenfeld RG: Generation of anti-insulin-like growth factor-binding protein-related protein 1 (igfbprp1/mac25) monoclonal antibodies and immunoassay: Quantification of igfbp-rp1 in human serum and distribution in human fluids and tissues. J Clin Endocrinol Metab 2003;88:3401-3408.

135 Yang QH, Liu DW, Long Y, Liu HZ, Chai WZ, Wang XT: Acute renal failure during sepsis: Potential role of cell cycle regulation. J Infect 2009;58:459-464.

136 Devarajan P: Update on mechanisms of ischemic acute kidney injury. Am Soc Nephrol 2006;17:1503-1520.

137 Boonstra J, Post JA: Molecular events associated with reactive oxygen species and cell cycle progression in mammalian cells. Gene 2004;337:1-13.

138 Rodier F, Campisi J, Bhaumik D: Two faces of p53:aging and tumor suppression. Nucleic Acids Res 2007;35:7475-7484.

139 Aregger F, Uehlinger DE, Witowski J, Brunisholz RA, Hunziker P, Frey FJ, Jörres A: Identification of IGFBP-7 by urinary proteomics as a novel prognostic marker in early acute kidney injury. Kidney Int 2014;85:909919.

140 Meersch M, Schmidt C, Van Aken H, Martens S, Rossaint J, Singbartl K, Gorlich D, Kellum JA, Zarbock A: Urinary TIMP-2 and IGFBP7 as early biomarkers of acute kidney injury and renal recovery following cardiac surgery. PloS One 2014;9:e93460.

141 Bihorac A, Chawla LS, Shaw AD, Al-Khafaji A, Davison DL, Demuth GE, Fitzgerald R, Gong MN, Graham DD, Gunnerson K, Heung M, Jortani S, Kleerup E, Koyner JL, Krell K, Letourneau J, Lissauer M, Miner J, Nguyen HB, Ortega LM, Self WH, Sellman R, Shi J, Straseski J, Szalados JE, Wilber ST, Walker MG, Wilson J, Wunderink R, Zimmerman J, Kellum JA: Validation of cell-cycle arrest biomarkers for acute kidney injury using clinical adjudication. Am J Respir Crit Care Med 2014;189:932-939.

142 Yu Y, Jin H, Holder D, Ozer JS, Villarreal S, Shughrue P, Shi S, Figueroa DJ, Clouse H, Su M, Muniappa N, Troth SP, Bailey W, Seng J, Aslamkhan AG, Thudium D, Sistare FD, Gerhold DL: Urinary biomarkers trefoil factor 3 and albumin enable early detection of kidney tubular injury. Nat Biotechnol 2010;28:470-477.

143 Munshi R, Johnson A, Siew ED, Ikizler TA, Ware LB, Wurfel MM, Himmelfarb J, Zager RA: MCP-1 gene activation marks acute kidney injury. J Am Soc Nephrol 2011;22:165-175.

144 Su L, Xie L, Liu D: Urine sTREM-1 may be a valuable biomarker in diagnosis and prognosis of sepsisassociated acute kidney injury. Crit Care 2015;19:281. 